\title{
Reactivation of chickenpox contracted in infancy
}

\author{
Kihei Terada, Shoji Kawano, Yumiko Hiraga, Tetsuro Morita
}

\begin{abstract}
Varicella zoster virus DNA in mononuclear cells was studied by the polymerase chain reaction to obtain virological evidence of reactivation in the children who had contracted chickenpox in infancy. The results appear to explain why chickenpox in infancy is a risk factor for herpes zoster in immunocompetent children.
\end{abstract}

(Arch Dis Child 1995; 73: 162-163)

Keywords: chickenpox, herpes zoster, polymerase chain reaction.

Varicella zoster virus causes chickenpox as primary infection; it can later be reactivated, causing herpes zoster. Based on lymphoproliferative assay studies of immunocompromised patients ${ }^{12}$ and elderly subjects, ${ }^{3}$ the mechanism of this reactivation is thought to be a deficiency in specific cellular immunity. However, the causes of herpes zoster in immunocompetent children remain unclear.

Chickenpox in infancy is a risk factor for herpes zoster in healthy children. ${ }^{45} \mathrm{~A}$ low response of specific immunity after chickenpox in infancy has been reported, and thereafter subclinical reactivation in the form of significant changes in specific humoral and/or cellular immunity was observed. ${ }^{6}$

To obtain virological evidence for the viral reactivation described above, we studied the varicella zoster virus DNA, as determined by the polymerase chain reaction (PCR), in the peripheral blood mononuclear cells (PBMCs) of children who had contracted chickenpox in infancy and children with malignancy.

\section{Subjects and methods}

The subjects were 27 normal children who were studied within 72 hours of the onset of chickenpox, 11 children aged less than 12 months and 12 over 12 months who had blood taken five or more weeks after the onset of chickenpox, and 17 children on maintenance treatment for malignancy who either had had chickenpox in the past $(n=16)$ or had been immunised with varicella vaccine $(n=1)$. We confirmed the diagnosis and past history of chickenpox by varicella zoster virus specific IgG and/or IgM antibody with the enzyme linked immunosorbent assay.

PBMCs were separated from heparinised blood by Ficoll-Hypaque gradient centrifugation. DNA extraction was carried out from $2 \times 10^{6}$ cells of PBMCs using a SepaGene kit (Sanko Junyaku, Tokyo). ${ }^{7}$ PCR was done as described by Koropchak et $a l^{8}$ and Ozaki et al ${ }^{9}$ using oligonucleotide sequences from varicella zoster virus gene 31 . The sequences of the outer ${ }^{8}$ and inner primers were 5'-GAGGAAGTTGAAGCCAGATC-3' and 5'-CTTCCAGTTCCAACCAACCG-3', $5^{\prime}$ - TCCAACCAACCGTTAAATGA-3' (57877-57897) and 5'-TTGAAGCCAGATCAATATTC-3' (57663-57683), respectively. After electrophoresis on a $2.5 \%$ agarose gel, a band of 235 base pairs was seen when samples contained varicella zoster virus DNA. We confirmed that some of the band can be hybridised with the inner probe by Southern blot. ${ }^{8}$

\section{Results}

The varicella zoster virus DNA sequences were detected in $21(77 \cdot 8 \%)$ of 27 children in the acute phase of chickenpox. Six of these had contracted chickenpox at $<1$ year old and all six were positive for the PCR. When blood samples were drawn at five weeks to 62.5 months after the onset, five (45\%) of 11 children who had contracted chickenpox at $<1$ year old were positive on at least one sample for the PCR, whereas none of the 12 children who had contracted it at $\geqslant 1$ year old were positive $(p<0.02$, Fisher's test; table 1). The longest period between the onset of chickenpox and the time blood was drawn among the positive samples was 3 years and 10 months. Six (35\%) of the 17 patients with malignancy during maintenance treatment were positive for the PCR (table 2). The healthy subjects with a positive PCR at least five weeks after the onset were not recognised as having herpes zoster or

Table 1 Results of the PCR for the varicella zoster virus $D N A$ sequences in PBMCs from the children who had contacted chickenpox at five or more weeks after the onset

\begin{tabular}{|c|c|c|c|}
\hline $\begin{array}{l}\text { Subject } \\
\text { No }\end{array}$ & $\begin{array}{l}\text { Age the child } \\
\text { contracted chickenpox }\end{array}$ & $\begin{array}{l}\text { Time after the } \\
\text { onset (weeks) }\end{array}$ & $P C R$ \\
\hline \multicolumn{4}{|c|}{$<1$ Year old at onset of chickenpox (age in months) } \\
\hline 1 & 5 & $\begin{array}{r}5 \\
25\end{array}$ & \multirow{10}{*}{$\begin{array}{l}\text { Negative } \\
\text { Negative } \\
\text { Positive } \\
\text { Negative } \\
\text { Negative } \\
\text { Negative } \\
\text { Positive } \\
\text { Negative } \\
\text { Positive } \\
\text { Positive } \\
\text { Positive } \\
\text { Negative } \\
\text { Negative } \\
\text { Negative } \\
\text { Positive } \\
\text { Negative }\end{array}$} \\
\hline 2 & 4 & $\begin{array}{r}6 \\
20\end{array}$ & \\
\hline 3 & 11 & 7 & \\
\hline $\begin{array}{l}4 \\
5\end{array}$ & $\begin{array}{r}10 \\
9\end{array}$ & $\begin{array}{l}8 \\
9\end{array}$ & \\
\hline 6 & 9 & 16 & \\
\hline 7 & 5 & $\begin{array}{l}20 \\
24\end{array}$ & \\
\hline 8 & 7 & $\begin{array}{l}30 \\
38\end{array}$ & \\
\hline 9 & 1 & 52 & \\
\hline 10 & 9 & 144 & \\
\hline 11 & 2 & $\begin{array}{l}184 \\
188\end{array}$ & \\
\hline \multicolumn{4}{|c|}{$\geqslant 1$ Year old at onset of chickenpox (age in years) } \\
\hline 1 tai & $2 \cdot 3$ & 5 & Negative \\
\hline 2 & $2 \cdot 8$ & 5 & Negative \\
\hline 3 & $2 \cdot 3$ & 5 & Negative \\
\hline 4 & 1.8 & 8 & Negative \\
\hline 5 & $1 \cdot 8$ & 8 & Negative \\
\hline 6 & 1.9 & 16 & Negative \\
\hline 7 & $2 \cdot 9$ & 32 & Negative \\
\hline 8 & $8 \cdot 8$ & 144 & Negative \\
\hline 9 & 6.9 & 172 & Negative \\
\hline 10 & $7 \cdot 2$ & 172 & Negative \\
\hline 11 & $13 \cdot \overline{8}$ & 240 & Negative \\
\hline 12 & $7 \cdot 5$ & 250 & Negative \\
\hline
\end{tabular}

Correspondence and reprint requests to: Dr Terada. Accepted 29 March 1995

Department of
Paediatrics, Kawasaki
Medical School, 577
Matsushima,
Kurashiki City,
Okayama 701-01,
Japan
K Terada
S Kawano
Y Hiraga
T Morita
Correspondence and reprint
requests to: Dr Terada.
Accepted 29 March 1995


Table 2 Results of the PCR for the varicella zoster virus DNA sequences in PBMCs from the patients with malignancy who had contracted chickenpox

\begin{tabular}{|c|c|c|c|c|}
\hline $\begin{array}{l}\text { Patient } \\
\mathrm{No}^{\star}\end{array}$ & Age/sex & Diagnosist & $\begin{array}{l}\text { Past history } \\
\text { of chickenpox }\end{array}$ & $P C R$ \\
\hline 1 & $14 / \mathrm{M}$ & NHL & 3 Years & \multirow{19}{*}{$\begin{array}{l}\text { Negative } \\
\text { Negative (after } 10 \text { weeks) } \\
\text { Negative } \\
\text { Negative } \\
\text { Positive } \\
\text { Positive } \\
\text { Negative (after } 24 \text { weeks) } \\
\text { Positive (after } 26 \text { weeks) } \\
\text { Positive (after } \\
\text { Negative (after treatment of herpes zoster) } \\
\text { Positive } \\
\text { Negative (after } 26 \text { weeks) } \\
\text { Positive } \\
\text { Negative } \\
\text { Negative } \\
\text { Negative } \\
\text { Positive } \\
\text { Positive (after } 10 \text { weeks) } \\
\text { Negative (after treatment of herpes zoster) } \\
\text { Negative } \\
\text { Negative } \\
\text { Negative } \\
\text { Negative } \\
\text { Negative }\end{array}$} \\
\hline 2 & $5 / \mathrm{M}$ & ALL & 1 Year & \\
\hline 3 & $20 / \mathrm{F}$ & CML & Unknown & \\
\hline 4 & $4 / F$ & Neuroblastoma & Unknown & \\
\hline 5 & $16 / \mathrm{M}$ & NHL & 5 Years & \\
\hline 6 & $2 / \mathrm{F}$ & Wilms' tumour & 4 Months & \\
\hline & & & & \\
\hline 7 & $14 / F$ & ALL & 3 Months & \\
\hline 8 & $16 / M$ & ALL & 3 Years & \\
\hline 9 & $13 / F$ & AML & 4 Years & \\
\hline 10 & $8 / F$ & ALL & Vaccination & \\
\hline 11 & $14 / \mathrm{F}$ & Sarcoma & 4 Years & \\
\hline 12 & $6 / M$ & APL & 3 Years & \\
\hline & & & & \\
\hline 13 & $16 / M$ & Sarcoma & Unknown & \\
\hline & 6/M & ALL & 1 Year & \\
\hline 15 & $17 / M$ & NHL & 5 Years & \\
\hline 16 & 9/M & MDS & 3 Years & \\
\hline 17 & $8 / \mathbf{M}$ & ALL & 1 Year & \\
\hline
\end{tabular}

* Patients Nos 3, 4, and 11 already had herpes zoster and No 9 had contracted a second form of chickenpox during maintenance therapy. Nos 6 and 8 developed clinical herpes zoster at 10 and 28 weeks, respectively, after the positive PCR. No 7 was treated with oral acyclovir for three weeks because of recurrent stomatitis

tNHL, non-Hodgkin's lymphoma; ALL, acute lymphocytic leukaemia; CML, chronic

myelocytic leukaemia; APL, acute promyelocytic leukaemia; MDS, myelodysplastic syndrome.

recurrent chickenpox during this observation period. However, two of the six patients with malignancy who had been positive for the PCR developed clinical herpes zoster at 10 and 28 weeks, respectively.

\section{Discussion}

The positive rate for the PCR of PBMCs in the acute phase of chickenpox in this study was $78 \%$ ( 21 of 27 children) within 72 hours after the onset as determined by the nested double PCR. This compares with rates of $67 \%$ (eight of 12 patients) within 24 hours after the onset as reported by Koropchak et al, ${ }^{8} 69 \%$ (24 of 35 patients) within 24 hours by Sawyer et al, ${ }^{10}$ and $100 \%$ (12 of 12 patients) within 72 hours by Ozaki et al. ${ }^{9}$

Patients with malignancy are at high risk for herpes zoster because they are immunocompromised. In this study, we detected varicella zoster virus DNA in PBMCs from six of the 17 patients with malignancy during maintenance treatment without clinical signs of herpes zoster and chickenpox. Wilson et al ${ }^{11}$ reported the detection of varicella zoster virus DNA in PBMCs from seven (19\%) of 37 varicella zoster virus seropositive bone marrow transplant recipients by the same PCR method of Koropchak et $\mathrm{al}^{8}$ and demonstrated virological evidence of subclinical reactivation of the virus, which had been previously suggested by significant changes in the antibody titres. ${ }^{1}$ Devlin et al reported the detection of viral amplification products by the PCR from PBMCs in four (25\%) of 16 normal elderly people of 60 years old or older and in a 39 year old woman without signs of herpes zoster. ${ }^{12}$

Ozaki et al reported that detection of varicella zoster virus DNA in PBMCs decreased with time and was undetectable after 15 days from the onset. ${ }^{13}$ Our preliminary experiment (data not shown) showed that the latest detection was at day 14 and day 21 after chickenpox in the children who had contracted chickenpox at $\geqslant 1$ year and at $<1$ year of age, respectively. Therefore, we think that the positive PCR in the normal children at five or more weeks after the onset suggests subclinical reactivation of the virus rather than chronic infection in PBMCs after acute infection. This virological evidence of viral reactivation in children who had contracted chickenpox in the first year of life appears to explain why chickenpox in infancy is a risk factor for herpes zoster in normal children.

Informed consent was obtained from the parents or guardian of the children according to the guidelines of the United State Department of Health and Human Services and those of Kawasaki Medical School.

This study was supported in part by a grant (5-502) from Kawasaki Medical School.

1 Ljungman $P$, Lönnqvist $B$, Gahrton G, Ringdén $O$, Sundqvist V, Wahren B. Clinical and subclinical reactiva tions of varicella-zoster virus in immunocompromised patients. $\mathcal{F}$ Infect Dis 1986; 153: 840-7.

2 Arvin AM, Pollard RB, Rasmussen LE, Merigan TC Cellular and humoral immunity in the pathogenesis of recurrent herpes viral infections in patients with lymphoma. $\mathcal{F}$ Clin Invest 1980; 65: 869-78.

3 Burke BL, Steele RW, Beard OW, Wood JS, Cain TD, Marmer DJ. Immune responses to varicella-zoster in aged. Arch Intern Med 1982; 142: 291-3.

4 Guess HB, Broughton DD, Melton LJ, Kurland LT. Epidemiology of herpes zoster in children and adolescents; a population-based study Pediatrics 1985; 76 : cents;

5 Terada K, Kawano S, Yoshihiro K, Yokobayashi A Miyashima H, Morita T. Characteristics of herpes zoster Miyashima H, Morita T. Characteristics of herpes zoster in otherwi.

6 Terada K, Kawano S, Yoshihiro K, Morita T. Varicellazoster virus (VZV) reactivation is related to the low response of VZV-specific immunity after chickenpox in infancy. $\mathcal{F}$ Infect Dis 1994; 169: 650-2.

7 Funato T, Hoshino A, Kawamura T. Evaluation of a commercial extraction kit (SepaGene) for DNA diagnosis. fournal of Medicine and Pharmaceutical Science 1993; 29: $1401-4$.

8 Koropchak CM, Graham G, Palmer J, et al. Investigation of varicella-zoster virus infection by polymerase chain reaction in the immunocompetent host with acute varicella. F Infect Dis 1991; 163: 1016-22.

9 Ozaki T, Masuda S, Asano Y, Kondo K, Namazue J, Yamanishi $K$. Investigation of varicella-zoster virus DNA by the polymerase chain reaction in healthy children with varicella vaccination. $¥ \mathrm{Med}$ Virol $1994 ; 42: 47-51$.

10 Sawyer $M H$, Wu YN, Chamberlin CJ, et al. Detection of varicella-zoster virus DNA in the oropharynx and blood of varicella-zoster virus DNA in the oropharynx and blood

11 Wilson A, Sharp M, Koropchak CM, Ting SF, Arvin AM Subclinical varicella-zoster virus viremia, herpes zoster, and $T$ lymphocyte immunity to varicella-zoster viral antigens after bone marrow transplantation. F Infect Dis 1991 ; 165: 119-26.

12 Devlin ME, Gilden DH, Mahalingam R, Dueland AN, Cohrs R. Peripheral blood mononuclear cells of the elderly contain varicella-zoster virus DNA. $\mathcal{F}$ Infect Dis 1992; 165: 619-22.

13 Ozaki T, Kajita Y, Asano Y, Aono T, Yamanishi K. Detection of varicella-zoster virus DNA in blood of children with varicella. f Med Virol 1994; 44: 263-5. 